$\begin{array}{ll} & \text { Etnográfica } \\ \text { etnográfica } & \text { Revista do Centro em Rede de Investigação em }\end{array}$

Antropologia

vol. $15(2) \mid 2011$

Vol. $15(2)$

\title{
Performances culturais: expressões de identidade nas festas da fronteira entre Brasil, Argentina e Uruguai
}

Cultural performances: forms of identity expression in festivities at the frontier between Brazil, Argentina and Uruguay

\section{Luciana Hartmann}

\section{(2) OpenEdition}

\section{Journals}

\section{Edição electrónica}

URL: https://journals.openedition.org/etnografica/918

DOI: 10.4000/etnografica.918

ISSN: 2182-2891

\section{Editora}

Centro em Rede de Investigação em Antropologia

\section{Edição impressa}

Data de publição: 1 junho 2011

Paginação: 233-259

ISSN: 0873-6561

\section{Refêrencia eletrónica}

Luciana Hartmann, «Performances culturais: expressões de identidade nas festas da fronteira entre Brasil, Argentina e Uruguai», Etnográfica [Online], vol. 15 (2) | 2011, posto online no dia 23 outubro 2011, consultado o 10 fevereiro 2022. URL: http://journals.openedition.org/etnografica/918 ; DOI: https://doi.org/10.4000/etnografica.918

\section{(c) (7) \&}

Etnográfica is licensed under a Creative Commons Attribution-NonCommercial 4.0 International License. 


\title{
Performances culturais: expressões de identidade nas festas da fronteira entre Brasil, Argentina e Uruguai
}

\section{Luciana Hartmann}

\begin{abstract}
As festas ocupam um importante papel na criação e no fortalecimento dos laços que unem parte da população da fronteira entre Argentina, Brasil e Uruguai, no caso, aquela que se identifica com a cultura gaúcha ou gaucha. Para melhor compreender o que a festa expressa da sociedade, investigo como ela o expressa sua performance. Neste artigo abordo duas festas, um desfile do Dia do Gaúcho e as criollas, considerando-as como performances culturais que representam, através de múltiplas linguagens, o imaginário que a população tem a respeito de si própria. A proposta deste artigo é, portanto, analisar, a partir de uma pequena etnografia de cada evento, de que forma as festas expressam estas "identidades de fronteira".

PALAVRAS-CHAVE: festa, performance cultural, fronteira, gaúcho, identidade.
\end{abstract}

NESTE ARTIGO ABORDAREI DUAS FESTAS TRADICIONAIS DA REGIÃO DA fronteira entre Brasil, Argentina e Uruguai, cujas características permitem que sejam consideradas como "performances culturais", no sentido dado por Singer (1972), ou seja, como formas de expressão artística e cultural que obedecem a uma programação prévia da comunidade, com uma sequência determinada de atividades, local próprio para sua ocorrência, horário definido de início e fim, delimitação entre performers e público e, principalmente, expressas através de meios comunicativos diversos, como narrativas, canto, dança, artes visuais, etc., chamados pelo autor de "mídia cultural".

Inicialmente procuro situar teoricamente a proposta analítica do artigo. $\mathrm{Na}$ sequência, após introduzir o contexto etnográfico em questão, apresento duas pequenas etnografias relativas às festas enfocadas e finalizo com um exercício comparativo entre estas duas manifestações performáticas. Minha proposta é analisar, a partir da descrição de cada evento, de que forma as festas 
expressam o que estou chamando de "identidade de fronteira": quais são os elementos escolhidos para representá-la, como estes elementos são organizados e que significados emergem destas performances. ${ }^{1}$

O conceito de "festa" é tomado aqui de maneira ampla, semelhante ao que Guss (2000) propõe com a expressão "formas festivas" (festive forms): uma variedade de eventos públicos como Carnaval, paradas, concertos, feiras, quermesses, funerais, festas de santos - procissões, competições esportivas, comemorações cívicas e demonstrações políticas e julgamentos.

Não poderia deixar de mencionar o clássico trabalho de DaMatta (1980b), "Carnavais, paradas e procissões", sobretudo pela filiação deste à obra de Victor Turner, autor seminal nos estudos da performance na antropologia, campo de pesquisa ao qual venho me dedicando. Nesta obra, DaMatta estabelece uma dicotomia entre os ritos orientados para toda a ordem nacional, que ajudam a construir e a cristalizar uma identidade nacional abrangente, e aquelas dramatizações programadas que, ao contrário, focalizam as identidades regionais ou locais. Em ambos DaMatta distingue um caráter "extra-ordinário", sendo que no domínio dos eventos extraordinários previstos pelo sistema social encontra ainda uma divisão entre aqueles altamente ordenados,

"[...] dominados pelo planejamento e pelo respeito (expresso na continência verbal e gestural), e os eventos dominados pela brincadeira, diversão e/ou licença, ou seja, situações onde o comportamento é dominado pela liberdade decorrente da suspensão temporária das regras de uma hierarquização repressora" (DaMatta 1980: 38).

Levando em conta esta categorização de DaMatta e considerando que minha análise se detém não sobre "ritos nacionais" mas sobre formas de comemoração mais locais, as criollas uruguaias e o desfile do Dia do Gaúcho, fica difícil afirmar que estas pertençam somente ao segmento da ordem e do respeito ou ao da diversão e da licença. Pelo contrário, como veremos adiante, a análise dos dados etnográficos leva a crer que, nestas festas da fronteira, as diversas características se combinam.

Esta oscilação entre a "cerimônia" e a "festividade" também é apontada por Amaral (2000a), que argumenta ser exatamente este caráter misto o elemento fundamental na definição da festa. Para ela, festa é, sobretudo, ambiguidade entre um objeto sagrado ou sacralizado e um comportamento profano.

I Esta etnografia é resultante da pesquisa de campo realizada durante meu doutorado, que tinha como foco principal a análise das performances narrativas de contadores de histórias da região. Como as festas são um espaço de legitimação e de aferimento do prestígio destes contadores, acabei fazendo algumas incursões etnográficas pelo universo destas. Maiores informações sobre o trabalho com os contadores podem ser encontradas em Hartmann (2004). 
Partindo de dois dos principais e antagônicos modelos teóricos das ciências sociais sobre a festa - o de Durkheim e o de Callois -, Amaral (1998) aposta na utilização de um modelo intermediário, que possibilitaria, de forma mais enriquecida, dar conta do universo multifacetado das festas brasileiras. De acordo com este modelo, a festa exerceria simultaneamente o papel de negar e reiterar (conforme grifa a autora) o modo como a sociedade se organiza, selecionando o que deve ser lembrado e o que será esquecido: a festa "é o espaço onde a sociedade se reconhece e escreve sua história tal como ela a compreende" (1998: 112)

No entanto, só é possível compreender o que a festa expressa da sociedade investigando como ela expressa - ou seja, temos aqui a ideia da festa como linguagem. Neste sentido, procuro entender as duas festas em questão enquanto "performances culturais" que expressam, através de múltiplas linguagens, o imaginário que a população tem a respeito de si própria, ou seja, como sua identidade é manifesta in performance. Para isso, adoto a perspectiva de Guss (2000: 23) de que somente na intersecção de formas e significados se pode perceber a identidade como realidade performatizada. Para o autor, é no estado festivo, acima de tudo, que estas identidades são imaginadas e criadas. Procuro aqui, então, compreender como as identidades gaúcha e gaucha são performatizadas no desfile do Dia do Gaúcho e nas criollas, conformando um aspecto desta "cultura da fronteira". ${ }^{2}$

Inspirada também por Amaral (1998, 2000a, 2000b), que vê a festa brasileira como um "fato social total", no sentido dado por Mauss, minha análise busca compreender como os diversos planos (econômico, político, moral, estético) se articulam sob a feição de performance nestas festas de fronteira. Esta análise, entretanto, não toma os significados como fixos, pois creio que os eventos só podem ser compreendidos a partir dos contextos nos quais foram produzidos e estes contextos estão continuamente se modificando, sendo que as festas rapidamente se rearticulam para assimilar estas mudanças.

A pesquisa de campo que deu origem a este trabalho foi realizada entre os anos de 2001 e 2002 e teve como centros de atuação, por um lado, as cidades de Santana do Livramento (Brasil) e Rivera (Uruguai), caracterizadas por sua "fronteira seca" (são cidades contíguas), e, por outro lado, as cidades de Uruguaiana (Brasil) e Paso de Los Libres (Argentina), distantes 14 quilômetros e separadas por um delimitador natural, o rio Uruguai. Todos estes núcleos urbanos podem ser considerados de médio porte: Uruguaiana tem 130.000 habitantes, Santana do Livramento 98.000 habitantes, o departamento todo

2 A noção de que há uma "cultura da fronteira” ligando as comunidades vizinhas dos três países em questão se confirmou na observação dos relacionamentos "intrafronteiriços", que criam uma identidade comum, e na escuta de narrativas e discursos que evidenciam que a população também se vê e se autoidentifica a partir desta base comum - a experiência de viver na fronteira (Hartmann 2006). 
de Rivera não possui mais de 105.000 habitantes e o pueblo de Cerro Pelado, onde ocorreram as criollas, conta com cerca de 2000 habitantes.

Todas estas cidades têm a maior parte de sua economia calcada na produção agropecuária (criação extensiva de gado de corte e/ou plantio de arroz). ${ }^{3}$ A maior parte desta produção é ainda hoje desenvolvida em grandes propriedades de terra chamadas nos três países igualmente de "estâncias".

Foi nas estâncias, com sua divisão hierárquica de trabalho e sua organização social próprias, que as sociedades de fronteira se estabeleceram e se desenvolveram. As pequenas aglomerações urbanas da região cresceram em função das necessidades de abastecimento e de comercialização da produção das estâncias. As cidades daí oriundas, portanto, sempre estiveram e permanecem na atualidade fortemente vinculadas ao campo, sofrendo influências do modo de vida que aí se desenvolve e tendo inclusive seu ritmo de funcionamento demarcado pela sazonalidade da produção rural. A ruralidade, desta forma, exerce um peso tão forte na região que, mesmo aqueles que não possuem vínculo direto com o campo, recebem ou percebem suas influências, pois mesmo as pessoas que habitam a zona urbana possuem elos familiares, de trabalho ou lazer com a zona rural.

O modo de vida das estâncias, as relações sociais nelas desenvolvidas e o tipo de trabalho executado são um importante fator de identidade entre os povos da fronteira. ${ }^{4}$ Como observa Côco Rodriguez, de 60 anos (Paso de Los Libres, Argentina): "Ya las costumbres de él hombre de frontera son distintas de las costumbres de otros lugares, no?" Neste contexto, a figura do gaúcho aparece como a representante do tipo humano local. ${ }^{5}$ Há gaúchos ou gauchos nos três países em questão e quando a população refere-se a estes sujeitos está remetendo ao trabalhador rural, em geral ao homem, ${ }^{6}$ peão ou trabalhador de estância, que tem um modus vivendi específico, relacionado à sua própria formação, a determinados comportamentos, hábitos, maneiras de vestir e mesmo posturas éticas e corporais. Ao longo de suas narrativas, era comum

3 Não se deve desconsiderar, no entanto, a importância do comércio local de importação/exportação (nem sempre realizado de forma legal - são os assim chamados "contrabandos").

4 Para Grimson (2000: 23), no entanto, o estudo da fronteira em si desafia qualquer noção estática, uniforme e não relacional de cultura e de identidade, pois deveria incorporar à sua perspectiva analítica não somente a "mescla cultural" como também a aliança e os conflitos sociais e políticos inerentes à condição de viver na fronteira.

5 Neste sentido, vejamos o que Leenhardt (2002: 28) comenta sobre a unidade cultural que transcende as fronteiras inscritas sobre os mapas da Argentina, do Brasil e do Uruguai: "Aquilo que [...] caracteriza este território, culturalmente, é a unidade simbólica do universo 'gaúcho' tal como ele foi construído na prática e na literatura, ao passo que, politicamente, é a consequência de três entidades geopolíticas, uma zona de conflitos entre três soberanias".

6 Sobre a constituição da masculinidade entre os sujeitos gaúchos, ver a tese de Leal (1989), Gauchos: Male Culture and Identity in the Pampas, além de artigos da mesma autora (1992a, 1992b). 
os contadores tecerem comentários sobre a concepção local do "ser gaúcho", como faz Don Heber, de 60 anos (Minas de Corrales, Uruguai):

“[...] que os costilhares do Prata significa: Buenos Aires, Banda Oriental e parte do Rio Grande, que era nosso também, né? Que o gaúcho, passando de Porto Alegre pra diante, assim já em Santa Catarina, não são mais gaúchos. Ainda algum toma chimarrão, mas são poucos". ${ }^{7}$

Tomazito Berruti, de 80 anos (Rivera, Uruguai), também comenta a respeito da formação do gaucho:

"Bueno, eso del gaucho hay que hablar mucho, porque el gaucho tampoco es sólo la cruza del indio con el español, el gaucho es un tipo, un producto de un ser que vivió en un determinado medio ambiente, condicionado a ciertas costumbres impuestas por la naturaleza..."

Um outro aspecto também recorrente nos discursos dos habitantes da fronteira diz respeito à profunda relação dos gaúchos/gauchos com o cavalo, motivo pelo qual receberam a alcunha de "centauros dos pampas": ${ }^{8}$

"O meu filho nasceu quase arriba de um cavalo, desde cinco anos andando a cavalo. Nas criollas ele gineteia com outros ginete. Gineteia em potro, gineteia em vacuno... Quatro prêmio ele já tem" (Margarita, 50 anos, Cerro Pelado, Uruguai).

"Eu nasci e me criei em estância. Com cinco ou seis anos eu andava no campo, eu andava a cavalo campereando" (Seu Luiz M. Leão, 100 anos, Uruguaiana, Brasil).

"O meu pai sempre dizia que pra domar, pra enfrear um cavalo era muito difícil... mas ele falava que ele aprendeu desde jovem a conhecer o animal, ser amigo do animal, aprendeu todo o trabalho de campo, que era obrigação do peão saber" (Seu Santos Reis, 63 anos, Uruguaiana, Brasil).

7 Chimarrão: infusão tradicional, muito difundida na região, é preparada em uma cuia ou cabaça, sorvida através de tubo metálico - a bomba - que possui um ralo na extremidade inferior.

8 "Centauro" teria sido a denominação dadas aos gaúchos que nas revoluções lutavam a cavalo (Nunes e Nunes 2000: 102). A referência, portanto, é bastante antiga e constantemente reiterada tanto na literatura quanto nas obras antropológicas produzidas sobre a região. Bastide (1980: 177), por exemplo, comenta dos gaúchos que acompanhavam os enterros a cavalo: "como se esses centauros não soubessem mais andar a pé”; Leal (1989) intitula um dos capítulos de sua tese "The Gaucho as the centaur of the pampas". 
A partir destes comentários, pinçados de um universo bem mais extenso, é possível verificar a existência de alguns referenciais que servem para identificar o ethos gaúcho/gaucho - que pode, como vimos, ser associado tanto a homens quanto a mulheres: a ideia de formação a partir do cruzamento de culturas, o comportamento moldado pela relação com o ambiente (aqui a importância da ruralidade), o hábito, comum nos três países, de tomar chimarrão ou mate, o desprendimento em relação a uma determinada nacionalidade (antes de tudo eram da fronteira $)^{9}$ e a relação com o cavalo. Estas são algumas das características que aparecem com maior constância nos causos e cuentos da fronteira e sua abordagem aqui vem no sentido de considerá-las como aspectos importantes na análise da cultura da região. Devo lembrar, entretanto, que a cultura da fronteira não se resume à cultura gaúcha/gaucha, ainda que, no contexto investigado (meio rural), esta seja preponderante.

Atualmente percebe-se uma crise no modo de viver e de pensar da região. As transformações pelas quais vêm passando as sociedades da fronteira, sobretudo no meio rural, devem ser observadas com especial pertinência para que as suas performances culturais - e, mais especificamente, suas festas - possam ser compreendidas. O espaço cedido da agropecuária para as empresas de forestación, a redução do tamanho das propriedades rurais, o crescente uso de tecnologia na área de produção, a instalação de rede elétrica e telefônica, asfaltamento das estradas, etc., tudo isso modifica as relações interpessoais, bem como a relação da comunidade fronteiriça com a "campanha". Como uma parcela de sua identidade - e da identidade gaúcha/gaucha - está justamente vinculada à "ruralidade", as festas como o desfile do Dia do Gaúcho servem como um espaço/tempo de recuperação e mesmo recriação deste sentido do rural no meio urbano. Já uma festa como as criollas, que ocorre a partir de impulsos identitários semelhantes, porém no meio rural, opera um movimento contrário, ou seja, além de reforçar práticas comuns entre os próprios habitantes da campanha, proporciona também o envolvimento da população urbana com estas práticas in loco.

Apresento abaixo uma pequena etnografia de um desfile do Dia do Gaúcho, ocorrido na cidade de Uruguaiana (Brasil), e das criollas que ocorreram no pueblo de Cerro Pelado (Uruguai).

\section{O DESFILE DO DIA DO GAÚCHO}

A instituição do Dia do Gaúcho iniciou-se há cerca de quarenta anos, pouco antes da criação do Movimento Tradicionalista Gaúcho (MTG). O MTG,

9 Como também percebe K. Müller (2002: 226), a partir de pesquisa realizada na mesma região: "Eles se dizem 'da fronteira', incluindo-se em uma área diferenciada e ampla, e deixam para regiões mais distantes, além das zonas urbanas, a responsabilidade pelos contornos nacionais”. 
fundado em 1966, é a entidade que congrega os grupos tradicionalistas do estado. O primeiro Centro de Tradições Gaúchas (CTG) surgiu em 1948, em Porto Alegre, formado por um grupo de estudantes secundários, provenientes do interior do Rio Grande do Sul. Descendentes de pequenos proprietários rurais ou de estancieiros já em processo de decadência econômica, estes jovens criaram um movimento urbano cujo objetivo era recriar e reviver práticas e valores rurais. Com a rápida expansão do movimento e a criação de novos CTG, os tradicionalistas tiveram que procurar o que era a tradição gaúcha. De acordo com Oliven (1990) - inspirado por um lado na teoria de Hobsbawm da invenção das tradições, e por outro nos depoimentos dos próprios tradicionalistas -, como o material encontrado fosse pouco expressivo, foi necessário inventar o que passaria a ser tomado como tradição. O desfile do Dia do Gaúcho representa, assim, uma das manifestações expressivas que dão vida a estas "tradições". ${ }^{10}$

Inicialmente defendida pelo líder republicano Júlio de Castilhos - ainda no final do século XIX -, a ideia de comemoração do dia 20 de setembro como Dia do Gaúcho foi aprovada como lei estadual em 1964 (Oliven 1990: 35, 36). Tomando a Revolução Farroupilha ${ }^{11}$ como fato histórico privilegiado para exaltação da identidade do povo gaúcho, o MTG comemora o dia 20 de setembro, data de início da Revolução, com grandes desfiles que marcam o encerramento de uma semana de atividades que une tradicionalistas de todo o estado do Rio Grande do Sul.

Esse dia é considerado feriado em muitas cidades do estado cujas ruas se preparam com larga antecipação para receber centenas de homens, mulheres e crianças que vêm devidamente trajados, desfilando a cavalo para um público que os recebe calorosamente. Em geral, os desfiles são pela manhã, com um trajeto previamente determinado pelas autoridades locais. A estas grandes paradas, que chegam a reunir quatro mil cavaleiros, aflui um grande número de peões de estância, suas esposas e filhos, alguns estancieiros e, representando o maior grupo, habitantes da cidade, todos igualmente filiados ao MTG. Há também alguns casos de convidados externos ao MTG, em geral ligados a movimentos tradicionalistas de outros países, como comenta Roberto Rodriguez (60 anos, Tomaz Gomensoro, Argentina):

10 Para maiores informações sobre a criação, os fundamentos, o desenvolvimento e a abrangência do MTG, ver os trabalhos de Oliven (1990, 1991, 1992a, 1992b).

11 A Revolução Farroupilha é o episódio mais exaltado da historiografia gaúcha. Em 1835, descontentes com o governo centralizador do Império do Brasil, os liberais gaúchos uniram-se num movimento revolucionário que propunha a igualdade política através do sistema federativo. Durante os dez anos de guerra civil, os Farrapos chegaram a fundar uma república separatista. Em 1845, com o estado economicamente arrasado e a população descontente, um acordo de paz foi estabelecido, sob condição de indenização do Império do Brasil aos chefes Farrapos (Flores 1997: 92-98). 
"Incluso yo he ido en desfile a Uruguaiana, hace años que voy... Una volta que se hizo un desfile grande por la Fiesta Internacional, me encontré con amigos argentinos que me habian conocido en Argentina, y nos volvimos a encontrar acá, en el Brasil, en Uruguaiana, en los desfiles que llevaran ahí. Son cosas que van quedando, son recuerdos lindos, entonces uno sembra una amistad, no?"

Os preparativos e as expectativas em relação a esse dia são grandes de todos os lados, inclusive daqueles críticos ao evento que, conforme escutei numa ocasião, não suportam ver as ruas "se encherem de bosta”. Muitos estancieiros chegam a enviar seus cavalos e os de seus peões com um mês de antecedência para a cidade, para que os animais se habituem com o movimento e os ruídos urbanos.

O desfile do dia 20 de setembro representa o ponto culminante de uma semana - intitulada Semana Farroupilha - repleta de atividades organizadas e coordenadas pelos CTG em parceria com as prefeituras locais. Entre estas está o transporte da "Chama Crioula", acesa no dia 14 de setembro, por grupos de gaúchos que percorrem a cavalo o trajeto entre uma cidade e outra, acampando em estâncias que lhes cedem "pouso". Todas as noites, nas sedes dos CTG - chamados "galpões", em alusão ao espaço de reunião dos peões nas estâncias - organizam-se "mateadas" (encontros para tomar chimarrão/mate), bailes, jantares com comida típica (churrasco, arroz de carreteiro, etc.) que visam, além de festejar a data, preparar o grupo para o desfile. Nestes há uma representação quase mimética do “cenário" e da ambientação rural na cidade.

Cheguei em Uruguaiana no dia 17 de setembro de 2001 e não tinha a intenção de assistir o desfile, mas estar no lado brasileiro da fronteira durante essa semana significa "respirar" (literalmente) tradicionalismo. É verdade que a população de equinos da cidade aumenta, e com eles o número de excrementos espalhados pelas ruas. Mas não é apenas o olfato que sente a transformação da cidade, visualmente também se é atingido pelo colorido das lojas que fazem promoções de bombachas (calças largas, presas por botões logo acima dos tornozelos) e vestidos de prenda (longos, com várias saias e repletos de fitas e rendas) e pela presença maciça das cores da bandeira do Rio Grande do Sul - vermelho, verde e amarelo - aludidas em placas, faixas e flâmulas que decoram as ruas.

Já na minha chegada fui convidada pela família que me hospedava para ir, na noite seguinte, a uma mateada num piquete tradicionalista (associação que possui a mesma estrutura de um CTG, porém é menor). Lá, Felipe e Rose, os amigos de meus anfitriões, nos receberam vestidos a caráter, ele de bombacha, bota e lenço no pescoço, e ela de vestido de prenda, com seus filhos também "pilchados" (vestidos com a indumentária gaúcha). Todos sentamos à volta de uma mesa, tomando mate e contando histórias. É interessante perceber 
que as atividades que antecedem o desfile comportam a participação de pessoas que não estão vinculadas institucionalmente ao MTG, mas que possuem afinidades com suas propostas ou laços de amizade ou parentesco com seus participantes.

No dia 20, os membros dos CTG se reuniram muito cedo, por volta das 6 horas da manhã, quando comeram churrasco, tomaram mate e realizaram os últimos preparativos, encilhando os cavalos e organizando grupos de crianças que desfilariam sobre caminhões decorados como um galpão.

Neste dia a avenida principal da cidade, chamada significativamente de Presidente Vargas - possivelmente o político gaúcho de maior expressividade nacional -, é fechada. Quando cheguei ao local, a avenida já estava ladeada por centenas de pessoas ávidas para assistirem o espetáculo, muitos também "pilchados" e tomando mate. Não era difícil perceber que grande parte do público possuía amigos, parentes ou conhecidos participando, pois havia verdadeira comoção, com aplausos e gritos, quando estes eram vistos passando pela avenida. Graças a isso, os pontos altos do desfile variavam de acordo com as demandas de cada grupo de espectadores.

Ao largo de toda avenida havia cordões de isolamento separando público e participantes do desfile. No ponto central do trajeto havia três palanques, mas apenas um estava ocupado com autoridades locais do MTG e representantes da prefeitura. Os outros possivelmente seriam um resquício do desfile do dia 7 de setembro (Dia da Independência do Brasil) -, do qual o desfile do dia 20 aproveita a estrutura. É em frente ao palanque central que os participantes fazem uma saudação às bandeiras (do município, do Rio Grande do Sul e do Brasil), com o gesto de tirar ou tocar a ponta do chapéu.

Apesar do cordão de isolamento, a relação entre público e participantes é intensa durante o desfile e não apenas os primeiros manifestam-se em relação aos segundos, mas também estes, quando avistam familiares, amigos ou mesmo o público que os elogia, respondem aos cumprimentos, acenam ou realizam alguma performance particular (empinando o cavalo ou cavalgando de lado, por exemplo). Isto ocorreu quando encontrei Seu Ordálio, contador de causos e antigo cabanheiro, de 92 anos de idade, assistindo o desfile com toda sua família. Seu Ordálio (figura 1), devidamente pilchado, acenava para os amigos que passavam e era constantemente cumprimentado e reverenciado por estes, demonstrando o apreço do qual é merecedor.

Jean Duvignaud (1983), em sua definição de festa, toma as formas de participação do público como elemento classificatório. O autor divide as festas em dois tipos: festas de participação e festas de representação. Nas primeiras estão incluídas as cerimônias públicas nas quais a comunidade participa integralmente, consciente dos mitos ali representados e dos símbolos utilizados. As últimas são aquelas que diferenciam "atores" e "espectadores". Enquanto os atores são em número restrito e participam diretamente, os espectadores são 


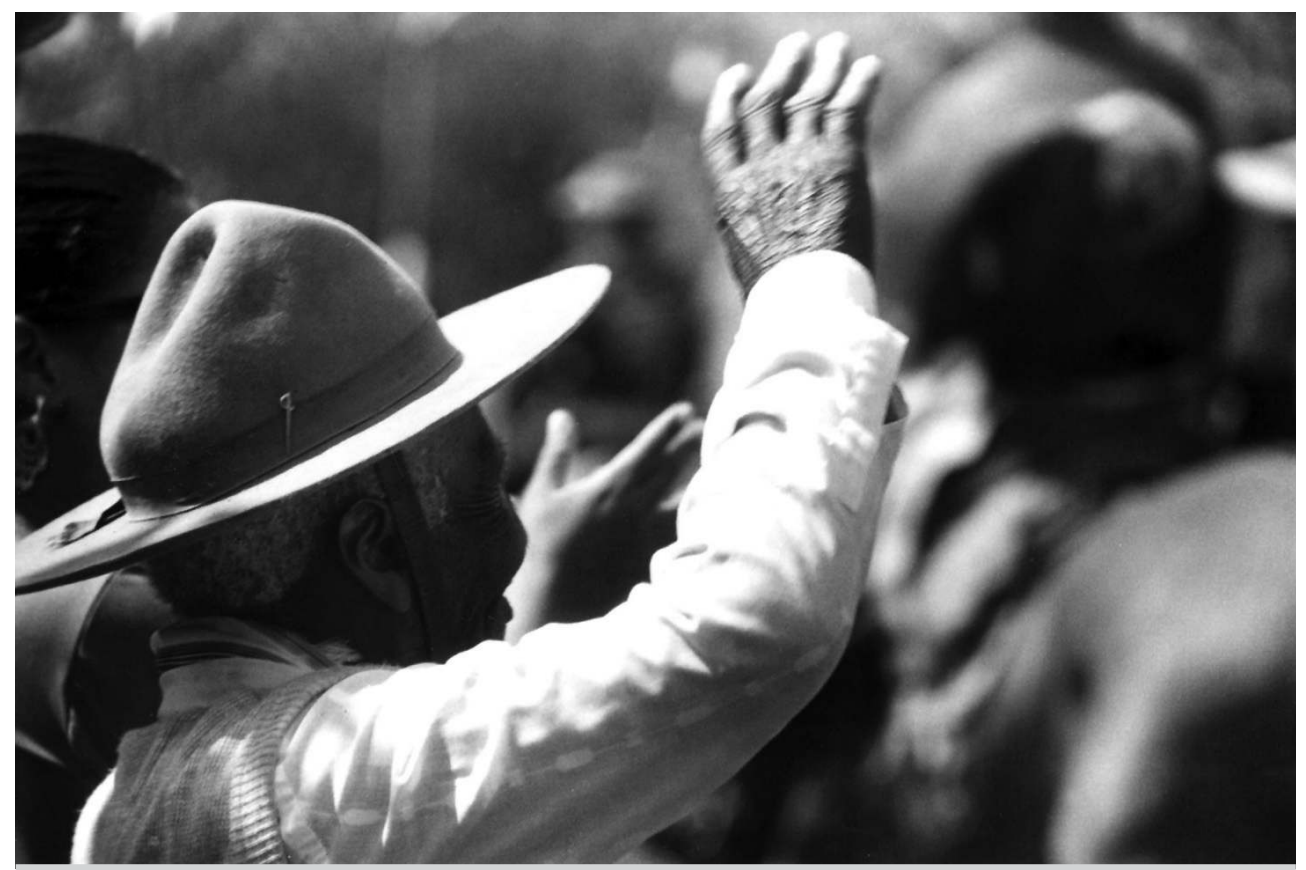

Figura 1 - Seu Ordálio Alves Fidels, de 92 anos, assistindo ao desfile do Dia do Gaúcho em Uruguaiana/RS, Brasil (2001).

muito mais numerosos e têm uma participação apenas indireta no evento, ao qual atribuem uma dada significação e pela qual são mais ou menos afetados. Embora todos (atores e público) reconheçam os mitos, ritos e símbolos representados, eles "percebem" o evento de modo diferente, conforme o papel que lhes é atribuído. De acordo com esta perspectiva, pode-se classificar o desfile do Dia do Gaúcho entre as festas de representação, já que há uma clara "divisão de papéis" entre os participantes do evento, que atuam de forma diferente. Todos contribuem, porém, de maneira absolutamente complementar para a sua plena realização, como procurei demonstrar acima.

Acompanhei o evento desde o momento da "concentração" dos participantes, no início da avenida, até o desfile propriamente dito. Despertou minha atenção a desenvoltura dos participantes em relação ao manejo dos cavalos, enquanto aguardavam a sua passagem pela avenida. Diversos participantes, inclusive, ao permanecerem horas esperando sua entrada na avenida, desenvolvem posturas de descanso, quase deitando sobre os cavalos (figura 2).

Dentre os participantes, há muitos que não possuem vínculos diretos com o meio rural, o que desperta críticas que os acusam de se "fantasiarem de gaúcho" apenas para o desfile. Neste caso, a "fantasia" é tomada depreciativamente, já que se pretende representar não uma ilusão, mas a própria realidade. Ainda que o desfile possua algumas semelhanças com paradas militares, 


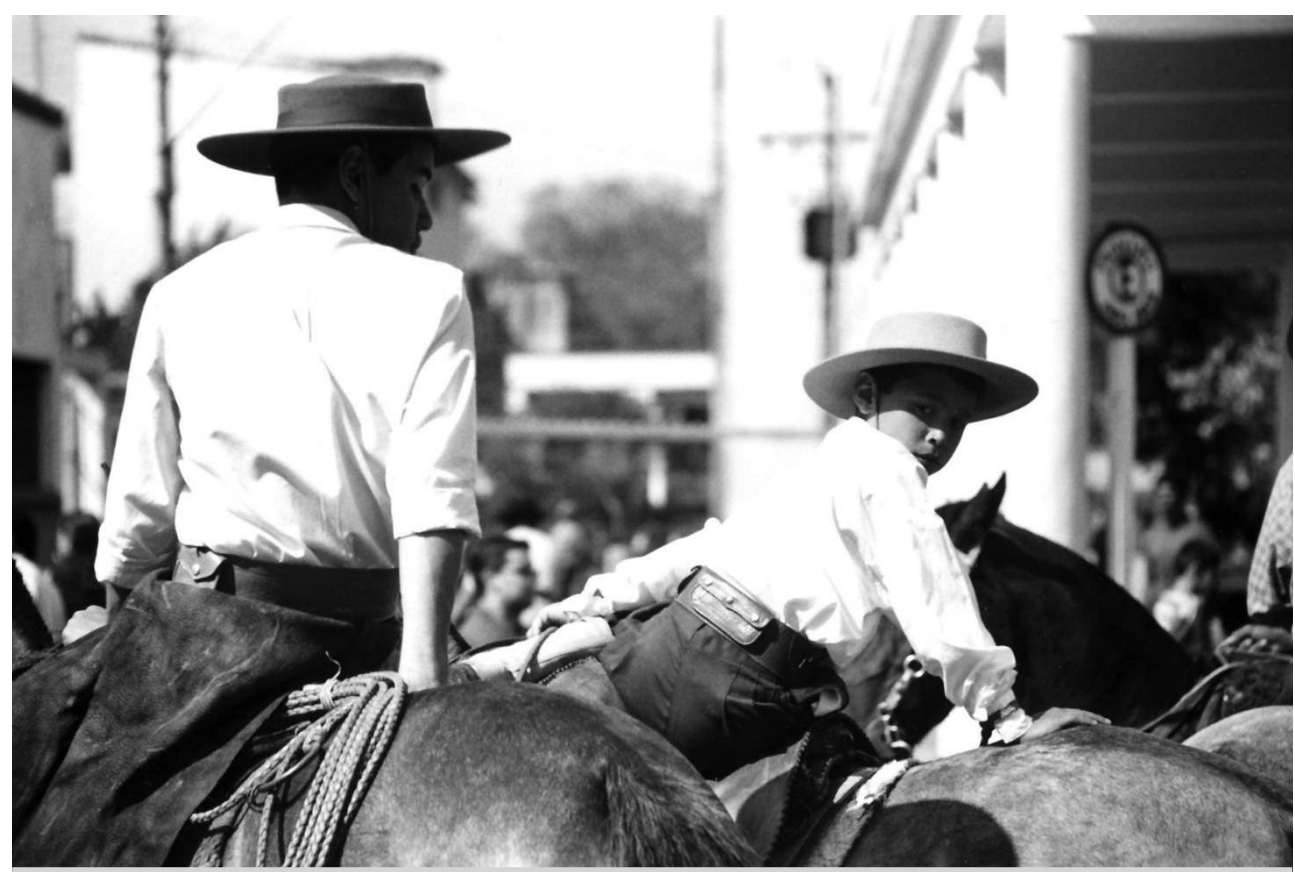

Figura 2 - Participantes do desfile do Dia do Gaúcho em Uruguaiana/RS, Brasil (2001).

pilchar-se, no entanto, não significa usar um uniforme. Assim, se por um lado o traje do desfile (ou a "fantasia") não é livre, por outro lado também não há uma uniformidade obrigatória. O que existe são normas ditadas pelo MTG regulamentando os tipos de "pilcha" masculina e feminina adequadas.

Embora o modus vivendi dos habitantes do campo seja plenamente conhecido pela população urbana da região, está claro que há diferença entre um peão e um funcionário público desfilando e isso fica patente durante a cavalgada.

Participam do desfile apenas grupos tradicionalistas (ligados ao MTG) - que representam a grande maioria - ou associações organizadas, ligadas ao meio rural. Estas últimas são compostas de membros - empregados e patrões - de "cabanhas" (estabelecimentos de criação de animais selecionados), de cooperativas de produtos agropecuários, de lojas de artigos de montaria e de vestuário gaúchos, e ainda de famílias de proprietários de estâncias que desfilam em nome de sua fazenda.

A abertura do evento se dá com a cavalgada de alguma das principais autoridades locais do MTG até o palanque, quando este "pede autorização" ao representante da municipalidade para iniciar o desfile. Sobre a questão da presença do poder público e da "autoridade" nas festas, Amaral (1998) aponta que, embora a festa negue a submissão da população ao poder instituído, ao prover as próprias necessidades através da associação de indivíduos, ela também usa 
este mesmo poder para conseguir realizar-se, quando solicita, por exemplo, a interdição das ruas.

O momento de performance propriamente dito (o espetáculo público) se resume, no entanto, aos poucos minutos percorridos no trajeto do desfile, representado, em Uruguaiana, por cerca de seis ou sete quarteirões. Ali, para o público leigo, fica difícil distinguir os peões dos grandes estancieiros, já que todos se esmeram em representar "papéis-símbolo" do tradicionalismo gaúcho, como "o peão" ou "a prenda". É possível perceber, no entanto, alguns diferenciais que vão desde o tom da pele (estancieiros, em geral, são brancos; entre os peões há mais negros) até elementos da indumentária (os peões em geral são mais enfeitados que os patrões) e postura.

Havia famílias inteiras desfilando, sendo que muitas crianças ainda de colo ou bastante pequenas desfilavam montadas com o pai ou a mãe. Vestidos com suas melhores "pilchas", muitas confeccionadas especialmente para a ocasião, durante o desfile todos se esmeram em demonstrar não apenas o requinte da vestimenta, mas o cuidado com o cavalo e a perícia na cavalgada. Pode-se perceber a importância destes aspectos no comentário de Dona Marica, de 93 anos: "Mas, é a maior beleza. Mas que luuuuuxo! Que modo de haver gente, minha guria!" Habituados ao trato direto com os animais, observei que alguns peões demonstravam um desempenho soberbo no momento do desfile, sendo sua performance aplaudida pelo público presente, como uma resposta ao seu talento, beleza ou destreza. Sahlins (1994: 37) aponta um destes aspectos, a beleza, como paradigma do político: seria através da utilização de uma dada construção estética, valorizada cultural e socialmente, que se instauraria o poder. Mas enquanto entre os chefes havaianos descritos por Sahlins o belo reforça as relações hierárquicas existentes, penso que entre os gaúchos, no dia do desfile, a beleza surge como uma possibilidade de rompimento (ainda que momentâneo) com estas relações e da afirmação do indivíduo frente ao grupo. ${ }^{12}$

Além da exibição de belos cavalos e de requintadas indumentárias, pode-se dizer que consta das performances a demonstração de uma postura ligada à destreza na cavalgada. E isso deve ser pensado coletivamente, já que todos os indivíduos desfilam organizados em grupos. Em 2001, por exemplo, um CTG desfilou com todos os seus membros portando lanças com pequenas flâmulas pregadas nas pontas. Eles passaram pela avenida divididos em três grupos, um portando flâmulas amarelas, outro vermelhas e outro verdes, ou seja, além da lança, arma utilizada na Revolução Farroupilha, as cores da bandeira do estado também eram por eles destacadas, mas este significado só poderia ser depreendido da apreciação do grupo na sua integralidade.

12 Verifica-se aqui também a importância da "estetização de si" (Veyne 1987) na constituição dos sujeitos gaúchos. 


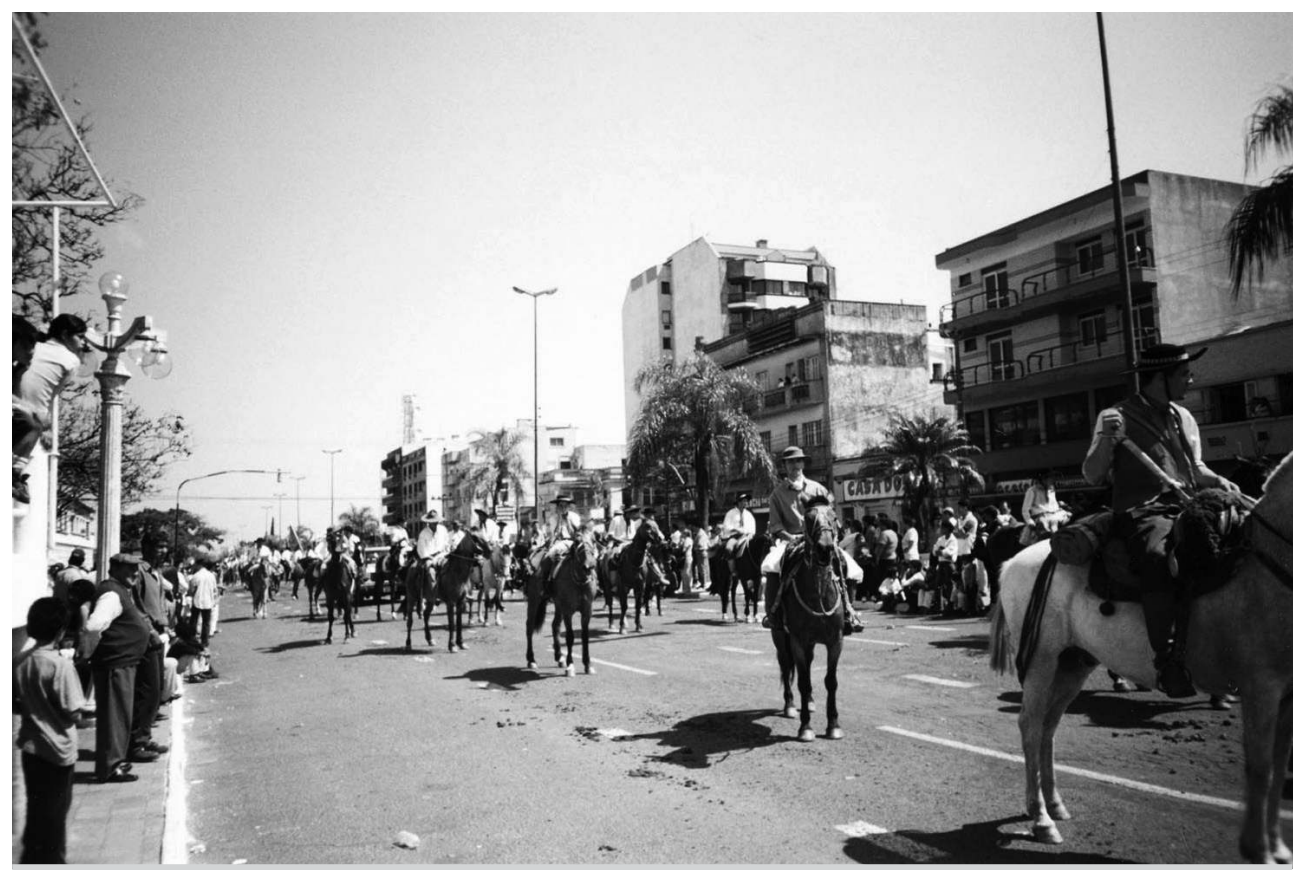

Figura 3 - Desfile do Dia do Gaúcho, na Avenida Presidente Vargas, em Uruguaiana/RS, Brasil (2001).

Durante o desfile, aplausos, gritos e assovios são ouvidos quando da passagem de crianças pequenas, devidamente pilchadas, sobretudo dedicados àquelas que desfilam a cavalo sozinhas. O mesmo ocorre com os idosos, que em vários grupos participam como uma espécie de "comissão de frente". Estas reações, me parece, indicam duas vertentes de uma mesma relação da sociedade com a questão da tradição - e de como esta se constrói e se afirma na própria performance. Arrisco dizer, por um lado, que a apreciação dos pequenos advém do fato de que estes demonstram uma incorporação precoce da tradição (simbolizada no uso das "pilchas" e no domínio do cavalo) e, por outro lado, que a comoção com a presença dos idosos relaciona-se com o valor a eles atribuído como referenciais na manutenção da tradição - eles são, como me disseram, exemplos da "tradição viva".

Considerando, entretanto, que mesmo os símbolos da "tradição" gaúcha não são unânimes, o desfile também funciona como uma ocasião em que os diferentes grupos posicionam-se em relação às regras ditadas pela diretoria do MTG e ao que tomam como as mais "autênticas" tradições gaúchas, buscando legitimidade através da aprovação do público. Assim, se o traje da mulher (sempre o que desperta maiores polêmicas) deve ser um longo vestido, cheio de babados, sem decote e sapatilhas baixas, vemos moças desfilando com as 


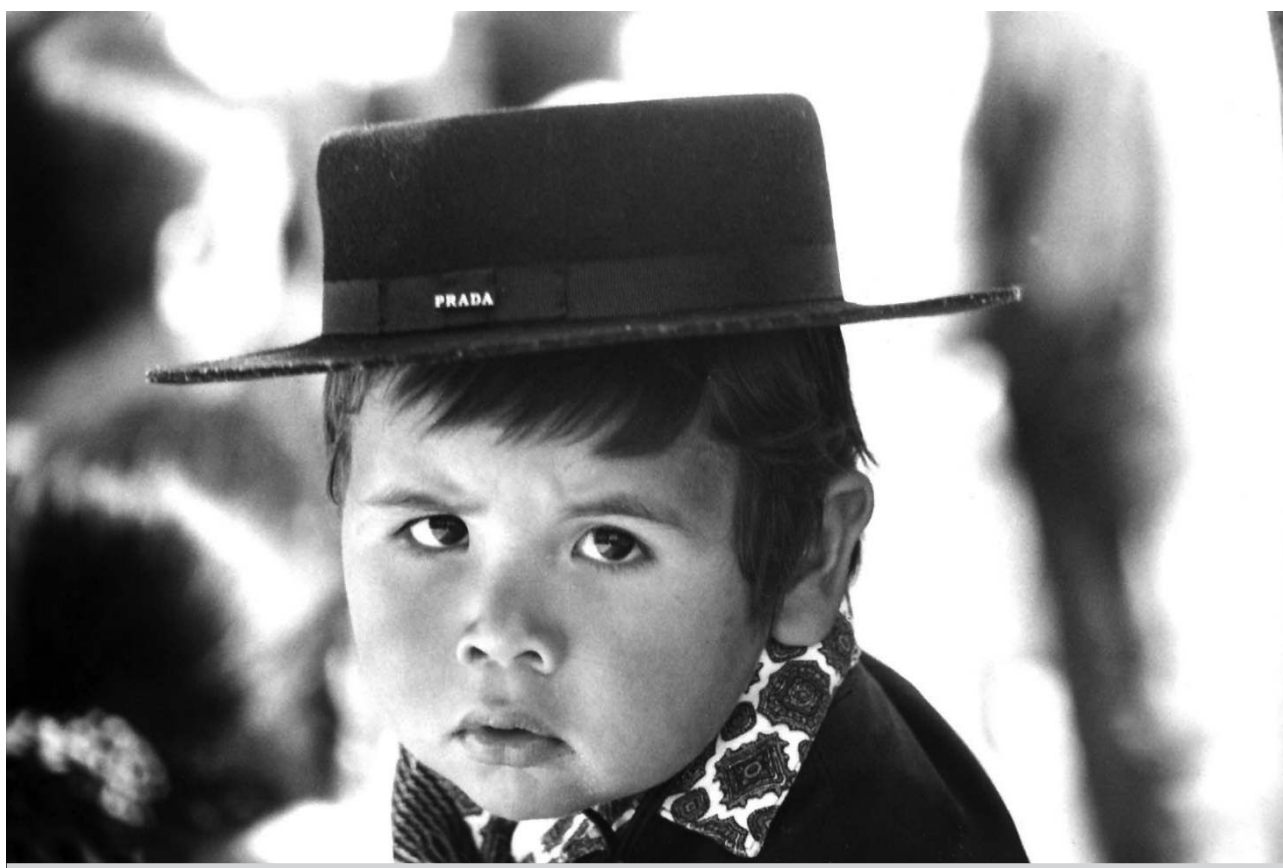

Figura 4 - Menino que assistia ao desfile do Dia do Gaúcho em Uruguaiana/RS, Brasil (2001).

mais variadas indumentárias, desde vestidos mais despojados, sem babados (pois há uma corrente que busca tornar o traje feminino mais verossímil) até bombacha, chiripá, ${ }^{13}$ botas de couro, e aproveitando a ocasião para demonstrarem também sua capacidade de cavalgar.

Neste evento se pode perceber várias esferas da vida cotidiana realçadas. A própria hierarquia que constitui as relações de trabalho, especialmente marcada nas estâncias, aparece refletida na hierarquia de funções que constitui, por exemplo, os CTG. ${ }^{14}$ Mas na performance não ocorre apenas um processo de espelhamento ou reprodução direta do mundo social, como já apontou Turner (1992). Como é sua característica, ela também é um momento de reflexão no qual são iluminados elementos muitas vezes obscurecidos no dia a dia. Assim, os conflitos entre patrões e empregados, entre homens e mulheres, negros e brancos, cidade e campo ganham forma no desfile,

13 "Vestimenta rústica, sem costuras, usada antigamente pelos homens do campo. É constituído de um metro e meio de fazenda que, passando por entre as pernas, é preso à cintura em suas extremidades por uma cinta de couro ou pelo tirador" (Nunes e Nunes 2000: 115-116).

14 Todos os cargos dos CTG reproduzem a nomenclatura da hierarquia de trabalho de uma estância; desse modo, o presidente é chamado "patrão", o responsável pelas atividades é chamado "capataz", e assim por diante. 
cavalgando lado a lado. E de alguma forma aqueles que se encontram em posição subordinada invertem essa relação de poder, exatamente por sobressaírem através da sua performance. Já os que estão em posição privilegiada procuram mantê-la, legitimá-la e assegurar sua permanência, "reforçando" ou "neutralizando" os conflitos latentes usando também os mesmos dispositivos de performance. Talvez por isso não se possa dizer que estes desfiles são compostos apenas por "gente da cidade" ou somente por "verdadeiros peões campeiros", mas, ao contrário, o que se vê é uma impressionante reunião de grupos representativos de grande parte da sociedade da fronteira.

Aqueles seis ou sete quarteirões tornam-se o palco onde uma determinada sociedade se constrói e se representa em suas mais variadas formas, especialmente se pensarmos no evento não apenas da perspectiva dos grupos que desfilam, mas também de todo o público que o acompanha, do policiamento que o cerca, de sua organização, transmissão e repercussão na mídia e inclusive daquele rapaz maltrapilho, que andava cambaleante, montado em seu cavalo de pau, ostentando uma bandeira rasgada do Rio Grande do Sul. Se, no limite, "tudo é festa durante o tempo da festa", essa multiplicidade de instâncias presentes nessa temporalidade faz dela, como propõe Amaral (2000a), um "fato social total".

Tomando em conta algumas de suas manifestações internas, como o desfile do grupo formado apenas de mulheres, as demonstrações individuais de habilidade de alguns peões, a presença de bebês e de senhores e senhoras idosos, as diferentes indumentárias utilizadas, etc., este evento constitui não apenas um espaço de alegria e comemoração mas também um "campo de batalhas" onde identidades são forjadas e comunidades são construídas (Guss 2000: 172).

Como se pode depreender desta rápida análise, este evento está direcionado para a própria população que o produz. É uma comemoração mais voltada para interior, para os semelhantes - que por este motivo podem compreender os códigos e as "mensagens" que estão sendo comunicadas - do que uma demonstração de símbolos e valores dirigida a um público que não os conhece. Como relata Oliven (1992a: 106), ao observar um festival de música "nativista" gaúcha: "Se me perguntassem o que as pessoas celebram, eu diria que elas celebram a si mesmas, individualmente e em grupos [...]. Acho que, na realidade, as pessoas vibram com a celebração da identidade gaúcha".

No Dia do Gaúcho a ênfase está colocada no fortalecimento de uma dada "tradição", que faz com que seja criada uma identidade entre seus participantes. Neste sentido, a festa é um elemento fundamental à manutenção de um grupo que corresponde aos indivíduos que se identificam com determinados aspectos da cultura gaúcha - aqueles adotados e ditados pelo MTG. ${ }^{15}$

15 Cabe salientar aqui, entretanto, que há diversos outros grupos na fronteira que não se identificam com a simbólica gauchesca - ver, por exemplo, o trabalho de Jardim (2001) sobre [continua] 
No dia seguinte ao desfile observei diversos grupos a cavalo, alguns compostos de famílias inteiras, que levavam pelas margens da estrada os animais de volta às respectivas estâncias. A imagem destes grupos, cavalgando tranquilos, trajados de maneira despojada (ao invés de camisa, lenço, chapéu e botas, vestiam camiseta, boné de propaganda, pés descalços ou sandálias), me trouxe uma visão concreta da transição entre a festa e o cotidiano. $\mathrm{O}$ aspecto "natural" dos cavaleiros naquele ambiente (pois na região é bastante comum encontrar pessoas cavalgando ao longo das estradas) contrastava enormemente com a feição "espetacular" do evento do dia anterior. Como observa Brandão (cit. em Amaral 1998: 111): "a festa toma a seu cargo os mesmos sujeitos, objetos e estrutura de relações da vida social e os transfigura. A festa exagera o real". Foi exatamente essa sensação que a imagem daquelas pessoas cavalgando na estrada me despertou. Havia inegavelmente algo de "real", de cotidiano no desfile, mas um real exagerado, estetizado, performatizado.

Voltando às questões abordadas acima, podemos revisar: são os corpos de todos os participantes do desfile que, envolvidos multissensorialmente, dão forma ao evento; esta performance representa um tempo e um espaço de reflexão para a população local a respeito de suas próprias relações; mas, e o elemento poético? Remetendo a Jakobson (1974) e à questão da combinação de elementos estranhos entre si, que só fazem sentido quando dispostos numa sequência coerente, podemos então verificar que a beleza do desfile (e aqui estética e poética - e política - se combinam) se dá justamente por uma combinação de cores e texturas, gêneros e classes, ruídos e cadências completamente impensáveis em outra ocasião que não este desfile. A começar por tantos cavalos juntos, e esporas enormes, lenços multicoloridos, passos muito lentos, tudo isso causaria estranhamento se não estivesse ali, per formare, para dar forma a desejos, a vontades, a necessidades de expressão, lazer e prazer daquela população. Para Norget (1996: 55), em seu trabalho sobre o Día de los Muertos em Oaxaca, no México, a "força performativa" (performative force) do ritual/festa reside em como as qualidades estéticas contribuem para o que se deseja comunicar ou para os efeitos que se deseja alcançar. No Dia do Gaúcho é justamente através da combinação extracotidiana, não usual, das diversas qualidades estéticas acima citadas que, creio, emerge o sentido e a força do evento.

Dialogando ainda com DaMatta (1980), que compreende que a rua fica "domesticada" no Carnaval, penso se no caso dos desfiles do Dia do Gaúcho não ocorre o contrário, já que ali a rua, espaço urbano, regrado, delimitado, é tomada por animais. O espaço da cultura é pisoteado pela natureza. E ainda que seja uma natureza já não tão selvagem, ela deixa suas marcas, seus sons, seus cheiros... 
No Dia do Gaúcho há uma organização mais "frouxa" por parte dos CTG, que permite que performances individuais aflorem e, como já foi dito, que, em alguns momentos, a hierarquia fortemente presente nestes grupos seja rompida ou transformada. Estes aspectos são abordados por Godinho (2000: 151), em relação às cerimônias comemorativas ocorridas no Sul de Portugal:

"[a festa] apela à criatividade, desviando-se do exequível, impõe a utilidade de aspectos sociais desvalorizados pelo grupo dominante, e desatrofia a capacidade de invenção dos indivíduos envolvidos: a edificação de novas gramáticas requer uma passagem pelo divertimento e pelo desregramento, e é contundente".

Finalmente, se estas performances culturais estão também relacionadas a uma forma de disputa pelo poder, e se o poder envolve uma escala hierárquica, onde necessariamente há dominação e subordinação, parece que encontramo-nos num paradoxo, pois ao mesmo tempo em que as performances parecem representar uma possibilidade de rompimento com o sistema hierárquico, elas também promovem uma maior adesão a este, já que propiciam o acesso à sua esfera mais desejada, aquela da dominação. É um círculo vicioso do qual não se tem muito como escapar. Mas sendo um círculo, a ideia de movimento permanece.

\section{AS CRIOLLAS}

As criollas de Cerro Pelado (Uruguai) aconteceram em agosto de 2001. Ainda que esse tipo de festa também apele à vivência e manutenção das tradições gauchas, diferentemente do desfile do Dia do Gaúcho estas não têm data fixa para ocorrer, podendo acontecer várias vezes num mesmo ano. Estas festas são organizadas por grupos de indivíduos que se associam com este objetivo, de acordo com as demandas das comunidades. ${ }^{16}$ No caso das criollas de Cerro Pelado, pequena comunidade rural a 76 quilômetros de Rivera, estas foram feitas com a finalidade de arrecadar fundos para a manutenção da policlínica local. Desta forma, as festas, ao mesmo tempo em que promovem entretenimento, disputa e diversão, também podem ser voltadas para a resolução de problemas reais, ocupando um importante papel na organização comunitária.

Um grupo formado basicamente por moradores da zona e professores do Liceu Rural responsabilizou-se pela organização do evento, desde a montagem

16 Embora no Uruguai não haja um movimento tradicionalista tão institucionalizado como no Brasil, na cidade de Tacuarembó, a cerca de 150 quilômetros da fronteira, é realizado um grande encontro denominado Patria Gaucha, que ocorre sempre no mês de março. Sua programação dura dois ou três dias, reunindo famílias de gauchos de todo o país, que aí acampam, fazem demonstrações de técnicas campeiras, cantam, dançam e participam de competições a cavalo, chamadas gineteadas. 
de sua estrutura física até a programação das atividades e divulgação para a comunidade. Durante os preparativos assisti a ensaios do grupo de danças das crianças, participei de discussões sobre a programação e, principalmente, percebi o envolvimento de praticamente toda a comunidade, desde os menores até os idosos, na realização da festa.

No dia do evento saí muito cedo de Rivera e rumei direto para a estância de Tomazito - grande narrador da região -, que fica a seis quilômetros do pueblito de Cerro Pelado. Lá eu poderia acompanhar a preparação de sua família para ir ao evento. Quando cheguei, já estavam todos (oito adultos e dez crianças) encilhando seus cavalos, as crianças vestindo-se de chinas $^{17}$ e gauchos, relembrando passos de dança ou os versos da poesia a ser declamada. Quase todos foram a cavalo para o local do encontro. Quando atingimos a estrada principal, percebi a aproximação de outras famílias que iam, também a cavalo, participar do evento. Em Cerro Pelado o clima era de emoção pela grande quantidade de pessoas reunidas e pela beleza do conjunto formado pelos cavaleiros. Todos haviam se reunido no centro do pueblito para que partissem juntos em direção ao local do evento - a cerca de dois quilômetros dali - numa espécie de parada de abertura.

Na partida do desfile, os cavaleiros foram aplaudidos pela população que os acompanhava. Na frente, com a honra e a responsabilidade de carregar a bandeira do Uruguai, ia Seu Domingo, um dos contadores que já havia me encantado com suas histórias (figura 5).

Na chegada ao local, novos aplausos e fogos de artifício. Lá havia tendas armadas para venda de bebidas, panchos (cachorros-quentes) e pastéis, e também organizava-se uma grande parrilla onde centenas de quilos de carne eram assados. Ainda pela manhã, a abertura do evento foi feita com a leitura de um texto, escrito por Bela, filha de Tomazito, exaltando as qualidades gauchas, e com apresentações de danças folclóricas infantis. Ao meio-dia chegou o padre para rezar a missa criolla, um culto ecumênico.

À tarde, após o almoço, aconteceram as provas chamadas de criollas, que consistem em palanqueadas (prova em que é medido o tempo que o cavaleiro leva para cumprir um percurso delimitado entre diversos "palanques"), tiros de laço (capacidade de laçar um boi), gineteadas (permanecer por mais tempo sobre um cavalo chucro), etc. São poucas as provas nas quais as mulheres participam, mas nas palanqueadas uma moça de aproximadamente quinze anos fez um belo espetáculo, classificando-se entre os primeiros lugares. Como esta prova

17 Equivalente masculino do gaucho, china era a denominação dada à mulher que vivia e trabalhava no campo, também na zona de fronteira do Brasil. A china caracterizava-se por seus traços indígenas ou mestiços e utilizava roupas de algodão, de corte simples e cores sóbrias. A palavra, porém, também era associada a mulheres "de vida fácil" (Nunes e Nunes 2000: 114), sendo, por este motivo, substituída pelos tradicionalistas brasileiros pela denominação "prenda", no sentido de jóia, relíquia, presente de valor. 


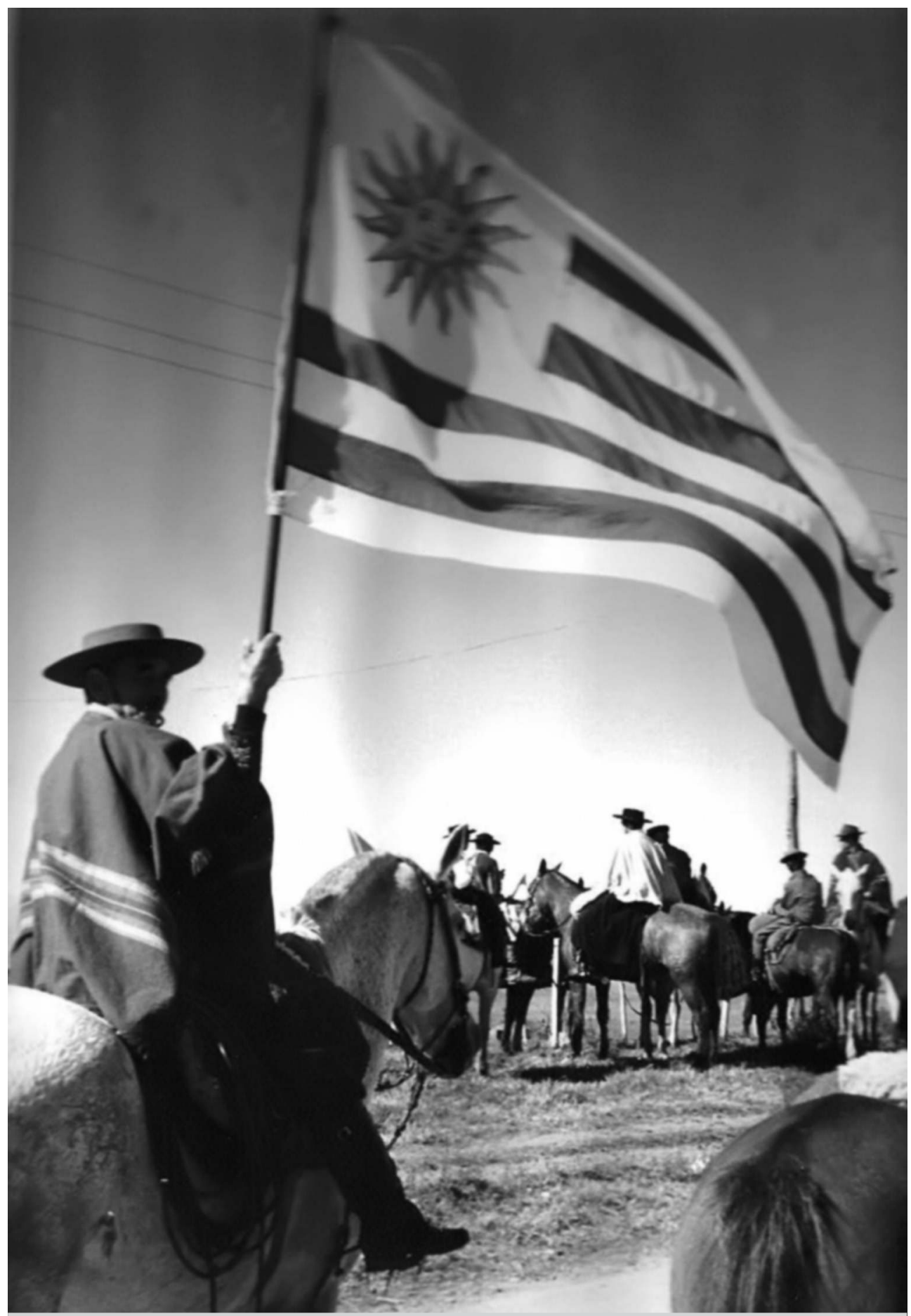

Figura 5 - Seu Domingo Romero, de 82 anos, carregando a bandeira do Uruguai na abertura das criollas em Cerro Pelado/Rivera, Uruguai (2001). 


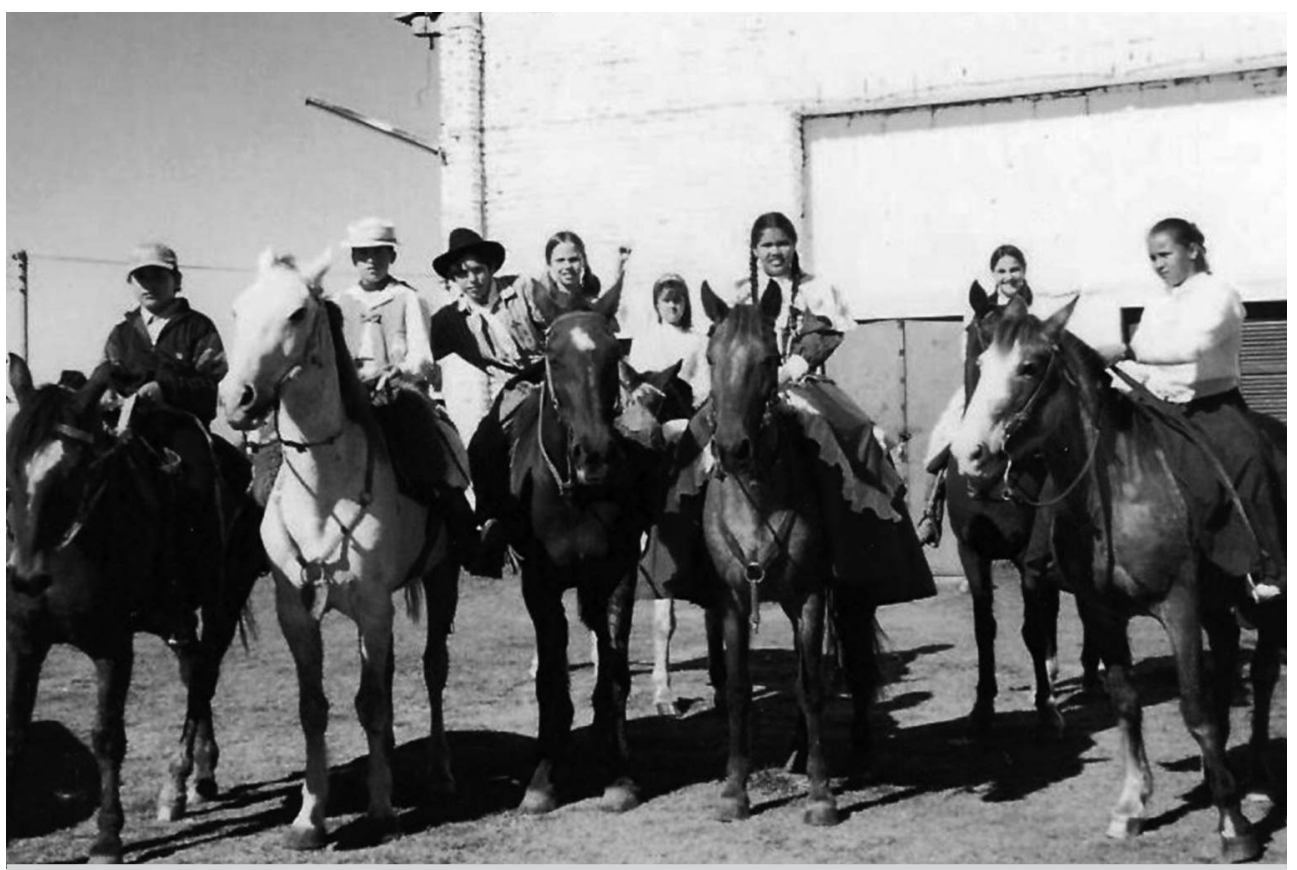

Figura 6 - Crianças que participavam da abertura das criollas em Cerro Pelado/Rivera, Uruguai (2001).

era dividida por faixas etárias, mas não havia uma categoria abaixo dos sete anos, foi aberta uma espécie de competição hors concours, na qual participaram duas crianças, Manuela e Venâncio, de cinco e seis anos, respectivamente. Este, sem dúvida, foi um dos pontos altos do dia, pois os dois, além de competirem palmo a palmo pelo primeiro lugar, demonstraram uma incrível capacidade de memorização, ao realizarem o trajeto corretamente, de domínio dos cavalos e de destreza para contornarem os palanques. Manuela acabou vencendo.

Esse acontecimento me fez refletir sobre a importância deste tipo de evento, especialmente para as crianças, que veem assim realçados os códigos culturais e comportamentais com os quais têm contato cotidianamente, incluindo formas de interação, posturas, o domínio do cavalo, o canto, a dança e a poesia tradicional. Esta espécie de socialização na tradição, ocorrida especialmente nas festas, sejam criollas ou desfiles do Dia do Gaúcho, prepara as crianças para responderem às demandas identitárias de seu grupo, ao mesmo tempo em que criam laços com grupos pertencentes ao "outro lado" (da fronteira).

As principais provas ocorreram numa mangueira (curral) que já existia no local. A disposição dos participantes durante as provas é bem demarcada: os homens que concorrem e os que auxiliam na organização da competição ficam dentro da mangueira; mulheres e crianças se mantêm fora, do outro lado da cerca que delimita o espaço. O policia também permanecia do lado de fora. 
Outra questão importante é relativa às posturas de descanso dos homens, que ao invés de sentarem-se em cadeiras, como as mulheres, agacham-se, sentam no chão ou ainda, debruçam-se sobre o cavalo. Outro fator a ser remarcado é relativo à indumentária utilizada neste evento: muitos homens usam suas bombachas - mais estreitas que as brasileiras, como sempre fazem questão de salientar, como índice de diferença - combinando com a cor da camisa ou do colete e é comum que este seja bordado com flores. Já as mulheres dividem-se entre aquelas que já cederam às influências brasileiras e vestem-se de prenda (o que é reprovado pela maioria), aquelas que se vestem com bombachas e botas e as que usam saias e blusas rústicas de algodão e pés descalços, numa alusão às chinas. Alguns homens e, sobretudo, muitas mulheres, entretanto, vão ao evento vestidos de modo mais urbano, com jeans e camisetas.

As criollas duraram a tarde toda e terminaram com o Sol já se pondo. Dali foram todos para um galpão próximo ao local, para uma peña folklórica. A peña é a parte mais festiva do evento, voltada à confraternização, e onde há maior contato entre grupos pertencentes às diferentes camadas da sociedade. Neste sentido, a peña, mais do que o momento de competição das criollas, caracteriza-se como uma festa de participação, no sentido dado por Duvignaud (1983).

A atividade teve início com a distribuição das medalhas relativas aos ganhadores das criollas e logo em seguida músicos da comunidade começaram a tocar milongas, chamamés, vaneirões, com seus violões e acordeões. O grande "contato" entre os participantes ocorre, literalmente, na dança, quando todos, puebleros, estancieiros, peões, maestras e maestros (professores/as), abuelas (avós), abuelos (avôs) e chiquilines (crianças), aos pares, procuram harmonizar seus corpos no ritmo da música. São justamente estes comportamentos - propícios para ocorrer em situações de festas, pois rompem com as hierarquias, as regras ou as condutas cotidianas - que constituem o caráter desafiador destas.

Esta real possibilidade de aproximação, igualando os sujeitos durante o tempo de uma dança, por vezes gera expectativas que, por não serem alcançadas, acabam por deflagrar conflitos reais, cuja resolução pode implicar em violência. $\mathrm{O}$ que posso aferir em relação à peña que observei, entretanto, é que, apesar desta transgressão temporária das relações instituídas, há normas implícitas que regem estes eventos e os conflitos emergem somente quando há o desconhecimento das normas ou o desejo explícito de desafiá-las.

Antes do fim da festa mais dois acontecimentos não programados ainda iriam marcar o evento: a morte de um cavalo, de causa não identificada (segundo os comentários poderia ter sufocado com a própria corda ou estar desidratado, pois ficara amarrado o dia todo sem água), e o incêndio de uma motocicleta, de um jovem peão da região, causado pelo próprio rapaz que, quando fora verificar se ainda havia combustível no tanque, esquecera de apagar o cigarro... Quanto à morte do cavalo, após a comoção geral e aglomeração 
em torno do animal, muito se ouviu a respeito, desde críticas ao dono que nem bem esperara que o couro do cavalo esfriasse e já estava retirando o couro das patas para confeccionar botas, até discussões sobre porque não se deve comer carne de cavalo (verdadeira interdição entre gaúchos e gauchos). Em relação ao incêndio da moto, passado o susto (afinal, o fogo ocorreu bem em frente à porta do galpão onde estava acontecendo o baile) e já de volta à peña, o episódio virou motivo de animadas conversas e de performances nas quais a cena era representada de forma cômica. É exatamente nestes momentos que ficam mais patentes as qualidades reflexivas das performances culturais. Em vários outros momentos das criollas estas qualidades também transpareceram, como no início do evento, quando o discurso de abertura conclamava à união dos orientales (uruguaios) sob o espírito do herói Artigas. ${ }^{18} \mathrm{~A}$ festa se estendeu quase até a meia-noite, quando todos já demonstravam fortes sinais de cansaço.

A princípio as criollas se parecem muito com alguns eventos organizados pelos CTG brasileiros, porém sem a institucionalização destes, pois esta era sobretudo uma atividade de vecinos, e com um objetivo bem claro: arrecadar dinheiro para a policlínica.

As criollas também se diferenciam do desfile do Dia do Gaúcho por se constituírem como uma festa rural. No entanto, pude perceber que, apesar deste caráter, muitos dos participantes, filhos ou netos de estancieiros da região, alguns dos quais competiram nas provas, vinham de Rivera.

A questão da participação conjunta de peões (empregados) e de filhos ou netos de estancieiros (patrões) nas competições também realça algumas diferenças. Estas se manifestam de acordo com o tipo de habilidade exigida para cada prova. Assim, na palanqueadas, onde devem ser demonstradas agilidade e destreza com o cavalo, além de habilidade para conduzi-lo através de um trajeto tortuoso, os primeiros lugares ficaram com os rapazes urbanos. Já nas gineteadas, tiros de laço e paleteadas, onde a experiência na lida campeira, como a prática da doma - domínio e equilíbrio sobre o animal -, do laço e o "conhecimento incorporado" 19 sobre o peso e a força dos animais contam mais, as medalhas ficaram com os peões.

As origens sociais distintas também podem ser percebidas, especialmente entre os competidores, na indumentária utilizada: enquanto os filhos de estancieiros combinam bombachas com camisetas e boinas, grande parte dos peões, ao contrário, ostentava, junto com suas bombachas, camisas de cores fortes, alguns ainda complementando a vestimenta com coletes ricamente bordados e chapéus com barbicacho de prata. Desta maneira, é possível perceber

18 Caudilho revolucionário, que pretendia a independência uruguaia e a criação de uma república independente formada pelo Uruguai, pelas províncias argentinas de Corrientes e Entre Rios e pelo estado do Rio Grande do Sul, marcando um importante episódio da história comum da região.

19 Desenvolvo a questão da construção do conhecimento através do corpo em Hartmann (2009). 
uma inversão de valores na forma como cada grupo se apresenta, pois os que ostentam maior riqueza são aqueles que ocupam a escala inferior da hierarquia social.

Por outro lado, poder-se-ia pensar também no grupo dos peões como aquele mais voltado para uma determinada elaboração estética e, de certa forma, poética (através da combinação especial de cores, uso de desenhos, grafismos, bordados...), ligada possivelmente a questões da identidade e masculinidade do gaucho - mais realçadas no meio rural -, mas também a construções culturais e individuais de beleza e gosto.

Outro aspecto que permite a análise das criollas como uma performance cultural é a característica multissensorial do evento, que faz com que desde a chegada ao local os corpos dos participantes respondam aos estímulos dos aromas (qualificando o ambiente pelo cheiro do churrasco, por exemplo), dos gostos (provando a carne assada ou outras iguarias lá vendidas), dos sons (dançando ou cantando), do calor (procurando as sombras das árvores), das cores (elogiando ou reprovando a cor da roupa de um amigo ou familiar), etc. ${ }^{20}$ Estes eventos propiciam novas experiências aos sujeitos que deles participam, e estas experiências, como no caso do incêndio da moto ou da vitória de Manuela na competição, serão em grande parte organizadas através das muitas narrativas que comentarão os episódios, conferindo forma e significado à sua experiência.

\section{A EMERGÊNCIA DE IDENTIDADES "DE FRONTEIRA" NO EXERCÍCIO COMPARATIVO DAS FESTAS}

Gostaria de concluir salientando alguns aspectos que podem ser depreendidos de uma perspectiva comparativa das duas festas, a partir da abordagem destas como performances culturais. Os critérios que embasaram esta comparação são resultantes da própria análise da etnografia, em diálogo com os diversos interlocutores, em campo, e com os referenciais teóricos utilizados ao longo do trabalho.

Em primeiro lugar, ambas as festas fazem um apelo à tradição, que é criada e fortalecida na performance. ${ }^{21}$ Nas duas festas constata-se um envolvimento da comunidade não apenas no momento do evento, mas em toda a sua preparação e execução; a participação intensa do grupo gera experiências que geram novas narrativas (círculo hermenêutico); ambas combinam tempo mítico com tempo presente. Guss (2000: 14) considera que o recurso à tradição muitas

20 Em seus trabalhos, Stoller (1989), Briggs (1996) e Langdon (1999) também vão demonstrar preocupação em dar conta das diversas mídias e recursos sensoriais utilizados em eventos performáticos, salientando especialmente a importância destes elementos para a construção e compreensão do seu significado.

21 Neste sentido, ver Schieffelin, que em artigo de 1998 considera a performance como uma forma de construção social da realidade. 
vezes opera uma neutralização e remoção do tempo real, deflagrando a criação de um passado mítico, destemporalizado. Nos dois eventos aqui abordados, se por um lado há realmente um apelo à figura destemporalizada do gaúcho/gaucho, por outro lado esta coexiste com figuras atuais, presentes, de homens e mulheres cujo cotidiano de trabalho e lazer ainda corresponde a muitos dos elementos ali realçados como "tradicionais". Penso que, neste caso, a eficácia do apelo à tradição, comprovada pelo engajamento das comunidades nas festas, tem relação direta com a reverberação dos elementos desta tradição na realidade.

Há, entretanto, diferenças entre os aspectos celebrados em um e em outro evento. O Dia do Gaúcho, por seu caráter urbano, por sua organização institucionalizada pelo MTG e sancionada/apoiada pelo poder público e pela relação menor de seus participantes com os papéis que representam no desfile, de certa forma "exagera o real". A identidade que é celebrada todo dia 20 de setembro expressa apenas uma parte do ethos gaúcho, exatamente a mais bonita, a mais rica, mais habilidosa, mais inteligente... O desfile comemora a "tradição" e o que ela representa para o MTG. Já nas criollas, um evento rural realizado, sobretudo, para os próprios habitantes da região (trabalhadores das estâncias, moradores dos pequenos pueblos, etc.), é a práxis cotidiana, a experiência dos sujeitos, que está em relevo (Schechner 1992; Turner 1981) e que é ali avaliada e premiada. Esta festa comemora o real (ou a ideia que a comunidade tem dele), como transparece no comentário de Alejandro, de 34 anos (Rivera, Uruguai):

"En las fiestas de campanha los tipos van, las asociaciones tradicionalistas, tipo CTG... Pero a parte [...] la gente que las hace, son la gente del campo! Viste eses viejos con las manos todas, como se dice, calejadas? Ahí está, viste, descalzos... Son gente del campo, son gente que trabaja".

Enquanto as criollas expressam emblemas locais, mais próximos do cotidiano dos envolvidos, no desfile do Dia do Gaúcho são expressos emblemas regionais, especialmente se pensarmos na Pampa como região e no gaúcho brasileiro como sinônimo de gaucho uruguaio e argentino - daí a presença, no desfile, de tradicionalistas dos países vizinhos. ${ }^{22}$

Também nos dois eventos há uma emergência e uma atualização de valores da cultura; ambos funcionam como um "campo de batalhas", mais direto no caso das criollas, onde há espaço para os sujeitos competirem corpo a corpo

22 O uruguaio Gonzalo Abella (2004: 74-75), no entanto, pondera: "El Mundo Gaucho, diverso por origen, tuvo además diversidades internas marcadas por regionalismos. Así, aún hoy em una fiesta tradicionalista oriental puede distinguirse claramente um gaucho de nuestro Norte fronterizo de outro de Rocha o Treinta y Três". 
nas provas, e menos direto nos desafios propostos pelas performances dos participantes do desfile; em ambas as performances se pode distinguir os três momentos que definem o aspecto extracotidiano das "performances culturais", na perspectiva de Schechner (1988: 158) - agregação, atuação/representação e dispersão - e, neste sentido, as duas podem ser consideradas performances únicas, que respondem a realidades sociais e históricas contemporâneas. Finalmente, tanto em um quanto em outro evento há uma alternância entre os ideais e a realidade, bem como há espaço para manifestações de ordem (desfile, cavalgada de abertura) e de desordem (liberdade gestual e de vestimenta, dança e divertimentos na peña folklórica), refletindo, criando e recriando a ambiguidade da vida social.

Negando e reiterando, simultaneamente, o modo como a sociedade se organiza, selecionando o que deve ser lembrado e o que deve ser relegado ao esquecimento, o que deve ser transformado e o que não deve, a festa se apresenta, talvez, como um mundo ideal, comandado pela imaginação. Ao proporcionar a representação plena do universo imaginado/recriado - com sua caracterização espacial, sua temporalidade deslocada do cotidiano, sua música, sua dança, suas vestimentas, seus odores e seus comportamentos próprios -, a festa torna-se uma ação coletiva que prova que o sonhado também pode ser vivido.

\section{BIBLIOGRAFIA}

ABELlA, Gonzalo, 2004, El Cielo de la Gaucheria: Hombres Gauchos, Mujeres Gauchas. Montevideu, Betum San Ediciones.

AMARAL, Rita de Cássia, 1998, "A alternativa da festa à brasileira", Sexta-Feira: Antropologia Artes e Humanidades, 2 (2): 108-1 15.

—, 2000a, "As mediações culturais da festa 'à brasileira", Trabalhos de Antropologia e Etnologia, 40 (1-2): 107-130, disponível em <http://www.n-a-u.org/Amaral-mediacoes. html>.

— , 2000b, "Sentidos da festa à brasileira", disponível em < http://www.naya.org.ar/congreso2000/ponencias/Rita_Amaral.htm>.

BASTIDE, Roger, 1980, "O pampa e o cavalo", em Roger Bastide, Brasil: Terra de Contrastes.

São Paulo/Rio de Janeiro, Difel, 168-182, trad. Maria Isaura Pereira de Queiroz, 10. ${ }^{\mathrm{a}}$ ed. BRIGGS, Charles, 1996, "Introduction”, em Charles Briggs (org.), Disorderly Discourse: Narrative, Conflict and Inequality. Nova Iorque e Oxford, Oxford University Press, 3-40.

DAMATTA, Roberto, 1980a, Carnavais, Malandros e Heróis. Rio de Janeiro, Zahar.

—, 1980b, "Carnavais, paradas e procissões", em Carnavais, Malandros e Heróis. Rio de Janeiro, Zahar, 35-65. 
DUVIGNAUD, Jean, 1983, Festas e Civilizações. Fortazela, Ed. UFC/Rio de Janeiro, Tempo Brasileiro, trad. L. F. Raposo Fontenelle.

FlORES, Moacyr, 1997, História do Rio Grande do Sul. Porto Alegre, Nova Dimensão, 6. ${ }^{\text {a }}$ ed. GODINHO, Paula, 2000, "Celebração como mecanismo de reiteração de uma cultura resistente: o caso do Couço (1958-1962)”, Etnográfica, IV (1): 129-152.

GRIMSON, Alejandro, 2000, "Introducción: ¿Fronteras políticas versus fronteiras culturales?", em Alejandro Grimson (org.), Fronteras, Naciones e Identidades: La Periferia como Centro. Buenos Aires, Ciccus/La Crujía, 3-39.

GUSS, David, 2000, The Festive State: Race, Ethnicity, and Nationalism as Cultural Performance. Berkeley e Los Angeles, University of California Press.

HARTMANN, Luciana, 2004, "Aqui nessa fronteira onde tu vê beira de linha tu vai ver cuento": tradições orais na fronteira entre Argentina, Brasil e Uruguai. Florianópolis, PPGAS/UFSC, tese de doutorado em Antropologia Social.

— 2006 , "Narrativas orais: uma porta de entrada para a cultura da fronteira entre Argentina, Brasil e Uruguai”, em Ligia Chiappini e Maria Helena Martins (orgs.), Cone Sul: Fluxos, Representações e Percepções. São Paulo, Hucitec, 167-190.

— 2009, "A memória na pele: performances narrativas de contadores de 'causos', Ilha: Revista de Antropologia, 9 (2): 215-245.

JAKOBSON, Roman, 1974, "Linguística e poética", em Linguística e Comunicação. São Paulo, Cultrix, 118-132, trad. Izidoro Bilkstein e José Paulo Paes.

JARDIM, Denise Fagundes, 2001, Palestinos no Extremo Sul do Brasil: Identidade Étnica e os Mecanismos Sociais de Produção da Etnicidade. PPGAS/Museu Nacional, tese de doutorado em Antropologia Social.

LANGDON, Esther Jean, 1999, "A fixação da narrativa: do mito para a poética da literatura oral”, Horizontes Antropológicos, 12: 13-36.

LEAL, Ondina Fachel, 1989, Gauchos: Male Culture and Identity in the Pampas. Berkeley, University of California, tese de doutorado.

— - 1992a, "Honra, morte e masculinidade na cultura gaúcha", em Sergio Alvares Teixeira e Ari Pedro Oro (orgs.), Brasil \& França: Ensaios de Antropologia Social. Porto Alegre, Editora da UFRGS, 141-150.

— gaúcha”, Cadernos de Antropologia, 7: 7-14.

LEENHARDT, Jacques, 2002, "Fronteiras, fronteiras culturais e globalização", em M.H. Martins (org.), Fronteiras Culturais: Brasil, Uruguai, Argentina. Porto Alegre, Ateliê Editorial, 27-34.

MÜLLER, Karla Maria, 2002, "Práticas comunicacionais em espaços de fronteira: os casos do Brasil-Argentina e Brasil-Uruguai”, em Ligia Chiappini e Maria Helena Martins (orgs.), Cone Sul: Fluxos, Representações e Percepções. São Paulo, Hucitec, 219-232.

NORGET, Kristin, 1996, "Beauty and the feast: aesthetics and the performance of meaning in the Day of the Dead, Oaxaca, Mexico”, Journal of Latin American Lore, 19: 53-64.

NUNES, Zeno Cardoso, e Rui Cardoso NUNES, 2000, Dicionário de Regionalismo do Rio Grande do Sul. Porto Alegre, Martins Livreiro, 9. ${ }^{\mathrm{a}} \mathrm{ed}$.

OLIVEN, Ruben G., 1990, “'O maior movimento de cultura popular do mundo ocidental': o tradicionalismo gaúcho”, Cadernos de Antropologia, 1: 1-46.

— 1991, "Em busca do tempo perdido: o Movimento Tradicionalista Gaúcho", Revista Brasileira de Ciências Sociais, 15: 40-52. 
OLIVEn, Ruben G., 1992a, A Parte e o Todo: A Diversidade Cultural no Brasil-Nação. Petrópolis, Vozes.

—, 1992b, "A polêmica identidade gaúcha”, Cadernos de Antropologia, 4: 3-56.

SAHLINS, Marshall, 1994, Ilhas de História. Rio de Janeiro, Zahar, trad. Barbara Sette.

SCHECHNER, Richard, 1988, Performance Theory. Nova Iorque e Londres, Routledge.

—, 1992, "Victor Turner's last adventure", em Victor Turner, The Anthropology of Performance. Nova Iorque, P.A. J. Publications, $7-20,2 .^{\mathrm{a}}$ ed.

SCHIEFFELIN, Edward L., 1998, "Problematizing performance", em Felicia Hughes-Freeland (org.), Ritual, Performance, Media. Londres e Nova Iorque, Routledge, 194-207.

SINGER, Milton, 1972, When a Great Tradition Modernizes. Chicago, University of Chicago Press.

STOLLER, Paul, 1989, The Taste of Ethnografic Things. Pensilvânia, University of Pennsylvania Press.

TURNER, Victor, 1981, “Social dramas and stories about them”, em W. J. T. Mitchell (org.), On Narrative. Chicago, University of Chicago Press, 141-168.

—, 1992, The Anthropology of Performance. Nova Iorque, P. A. J. Publications, 2. ${ }^{\text {a }}$ ed.

VEYNE, Paul, 1987, Indivíduo e Poder. Lisboa, Edições 70.

Cultural performances: forms of identity expression in festivities at the frontier between Brazil, Argentina and Uruguay - Luciana Hartmann - Departamento de Artes Cênicas, Universidade de Brasília (UnB), Brazil • luhartm@yahoo.com.br.

Festivities play a relevant role in building and bracing bonds between people living at the frontier region between Argentina, Brazil and Uruguay, the area relating to the gaúcho or gaucho culture. In order to better understand the meaning of festivities in this society, I investigate how they express it - their own performance. This paper focuses on two kinds of festivities: the Gaúcho Day parade and the criollas. Both can be seen as cultural performances representing, through multiple idioms, the self-image of the local population. Based on a brief ethnography of these happenings, my intention is to analyze in which way these festivities express such "frontier identities".

KEYWORDS: feast, cultural performance, frontier, gaucho, identity. 